\title{
DISERTASI
}

\section{POTENSI DIAGNOSTIK OUTER MEMBRANE PROTEIN \\ BM 58 kDa SHIGELLA FLEXNERI SEBAGAI \\ DIAGNOSIS DINI SHIGELLOSIS}

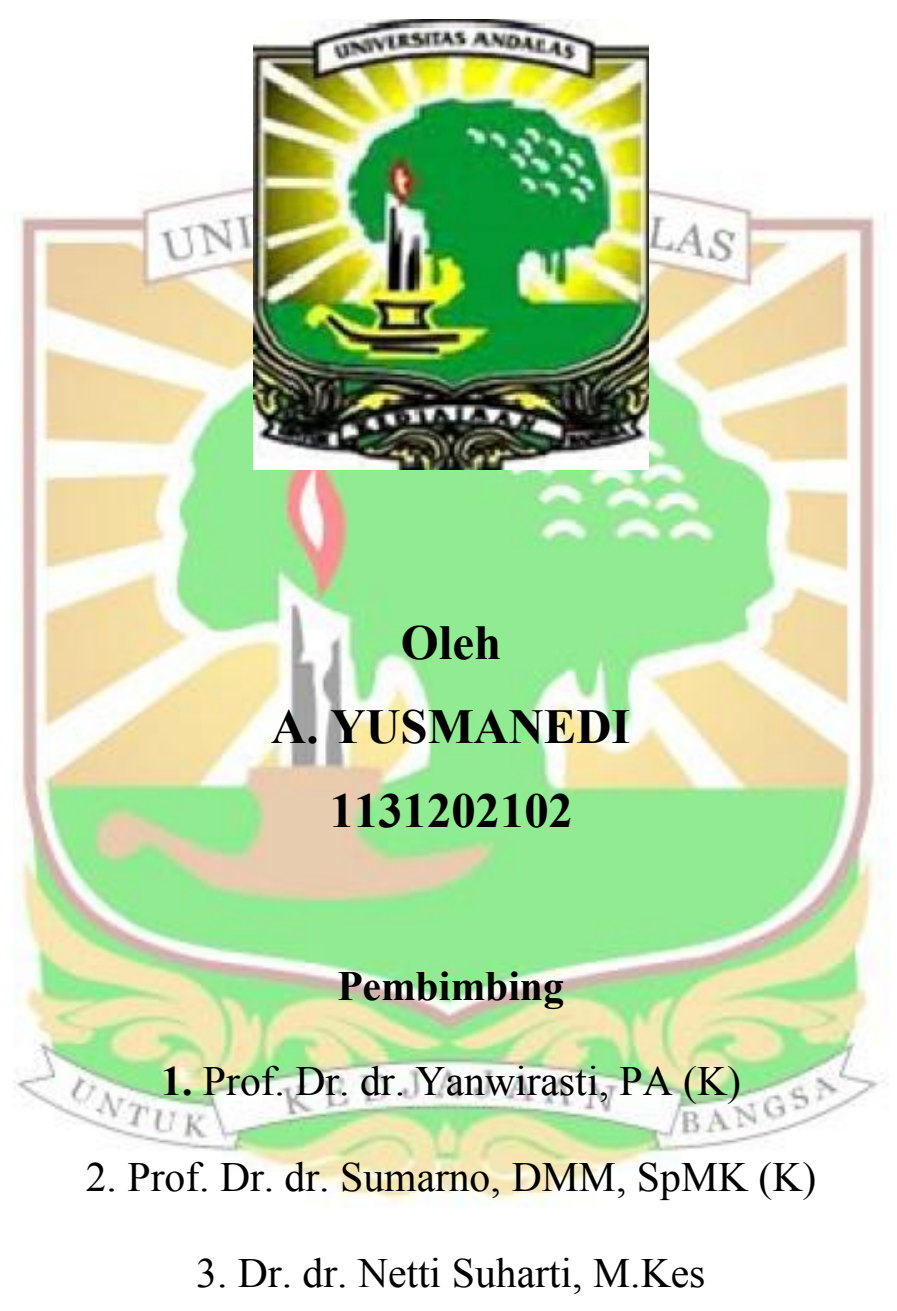

PROGRAM PASCASARJANA

FAKULTAS KEDOKTERAN

UNIVERSITAS ANDALAS

PADANG 


\title{
POTENSI DIAGNOSTIK OUTER MEMBRANE PROTEIN \\ BM 58 kDa SHIGELLA FLEXNERI SEBAGAI DIAGNOSIS DINI SHIGELLOSIS
}

\author{
Oleh : A. Yusmanedi (1131202102) \\ (Dibawah bimbingan : Prof. Dr. dr. Yanwirasti, PA(K)., Prof. Dr. dr. H. Sumarno, \\ DMM, SpMK(K). dan Dr. dr. Netti Suharti, MKes.)
}

\begin{abstract}
ABSTRAK
Diare masih merupakan masalah utama di dunia, jumlah kematian akibat diare terutama bakteri Shigella spp di Indonesia dan dunia masih tinggi, sehingga memerlukan penanganan yang baik. Diagnosis diare oleh Shigella spp dilakukan dengan pemeriksaan secara klinis dan laboratorium dengan melakukan pemeriksaan kultur. Hasil kultur setidaknya dibutuhkan waktu 3 hari atau lebih dan tidak dapat dipersingkat, maka diperlukan suatu tes serologi yang mudah, tepat dan cepat untuk mendiagnosis Shigellosis. Tujuan dari penelitian ini adalah untuk menganalisis profil bakteri penyebab diare di RSUD Prov KEPRI Tanjung Pinang, mengetahui respon maksimal molekul sub unit pili dan OMP S. flexneri terhadap s-Iga saliva penderita Shigellosi, membandingkan sensitivitas dan spesifisitas molekul adhesi sub unit pili dan OMP bakteri S. flexneri apakah sama baiknya dengan baku emas kultur dalam mendiagnosis penderita Shigellosis.

Jenis penelitian ini merupakan uji diagnostik eksploratif menggunakan molekul adhesi sub unit pili dan OMP penderita Shigellosis. Sebagai standar emas untuk diagnosis Shigellosis adalah adanya bakteri Shigella flexneri pada pemeriksaan kutur apusan mukosa anus/ feses penderita diare. Penelitian dilakukan di IGD RSUD Prov KEPRI Tanjung Pinang dan Laboratorium Biomedik Fakultas Kedokteran Universitas Brawijaya Malang selama 2 tahun. Subyek penelitian adalah semua kasus diare yang memenuhi kriteria dan bersedia menjadi responden yang berjumlah 48 responden.

Hasil dari penelitian ini menunjukkan bahwa penyebab terjadinya diare oleh bakteri terbanyak adalah disebabkan oleh jenis bakteri Escherichia coli (19\%) berada diurutan pertama, kemudian disusul bakteri Shigella flexneri (14\%) pada urutan kedua, molekul protein spesifik yang dapat direspon maksimal oleh s-IgA saliva penderita Shigellosis adalah OMP BM 58 kDa, molekul sub unit pili BM 58 kDa bakteri Shigella flexneri mempunyai sensitivitas 57\% dan spesifisitas $51 \%$ dengan tingkat akurasi lemah dibandingkan baku emas kultur dalam mendiagnosis Shigellosis, sedangkan molekul OMP BM 58 kDa Shigella flexneri mempunyai sensitivitas $85 \%$ dan spesifisitas $73 \%$ dengan tingkat akurasi baik mendekati baku emas kultur dalam mendiagnosis Shigellosis.

Dari hasil penelitaian dapat disimpulkan bahwa OMP BM $58 \mathrm{kDa}$ Shigella flexneri memiliki kriteria yang baik sebagai potensi diagnosis dini Shigelosis penderita diare.
\end{abstract}

Kata kunci: Molekul Adhesi subunit Pilli, Outer Membran Protein (OMP), Diare. 


\title{
POTENTIAL DIAGNOSTIC OUTER MEMBRANE PROTEIN BM 58 kDa SHIGELLA FLEXNERI EARLY DIAGNOSIS SHIGELLOSIS
}

\author{
By : A. Yusmanedi (1131202102) \\ (Under the Guidance : Prof. Dr. dr. Yanwirasti, PA(K)., Prof. Dr. dr. H. Sumarno, \\ DMM, $\operatorname{SpMK}(K)$. and Dr. dr. Netti Suharti, MKes.)
}

\begin{abstract}
Diarrhea is still a major problem in the world, the number of deaths from diarrhea, mainly bacteria Shigella spp in Indonesia and the world is still high, so it requires a good handling. Diagnosis of diarrhea by Shigella spp performed by clinical examination and laboratory examination culture. Results of culture takes at least 3 days or more and can not be shortened, it would require a serological test that is easy, accurate and fast to diagnose Shigellosis. The purpose of this study was to analyze the profile of diarrheal bacteria in the general hospital Riau Islands province of Tanjung Pinang, to analyze the molecular weight of pili subunit protein and OMP of $S$. flexneri bacteria and to analyze the response of pili subunit adhesion molecule and OMP of Shigella flexneri whether to have sensitivity and specificity Which is good for the diagnosis of Shigellosis.

This research is a explorative diagnostic test using molecule adhesion pili subunits and OMP patients with Shigellosis. As the gold standard for the diagnosis of shigellosis is the presence of bacteria Shigella flexneri on the examination of the anal mucosa smear kutur / stool with diarrhea. The study was conducted in the ER general hospital Riau Islands Province of Tanjung Pinang and Biomedical Laboratory Faculty of Medicine, University of Brawijaya for 2 years. Subjects were all cases of diarrhea were eligible and willing to become respondents totaling 48 respondents.

The results of this study indicate that the cause of diarrhea by most bacteria is the type of bacteria Escherichia coli was first sequence, followed by Shigella flexneri bacteria in the second sequence. Specific protein molecules that can be responded maximally by saliva s-IgA patients Shigellosis is BM $58 \mathrm{kDa}$, the $58 \mathrm{kDa}$ sub-unit of Shigella flexneri bacteria had a sensitivity of $57 \%$ and a specificity of $51 \%$ with a low degree of accuracy compared to the golden culture standard in diagnosing Shigellosis, whereas the BM $58 \mathrm{kDa}$ Shigella flexneri OMP molecule had a sensitivity of $85 \%$, and a specificity of $73 \%$ which both approach the golden standard of culture in diagnosing Shigellosis.

From result of research can be concluded that OMP BM 58 kDa Shigella flexneri have good criterion as potential early diagnosis of Shigelosis of diarrhea patient.
\end{abstract}

Keywords: Molecule Adhesion subunit Pilli, Outer Membrane Protein (OMP), diarrhea. 


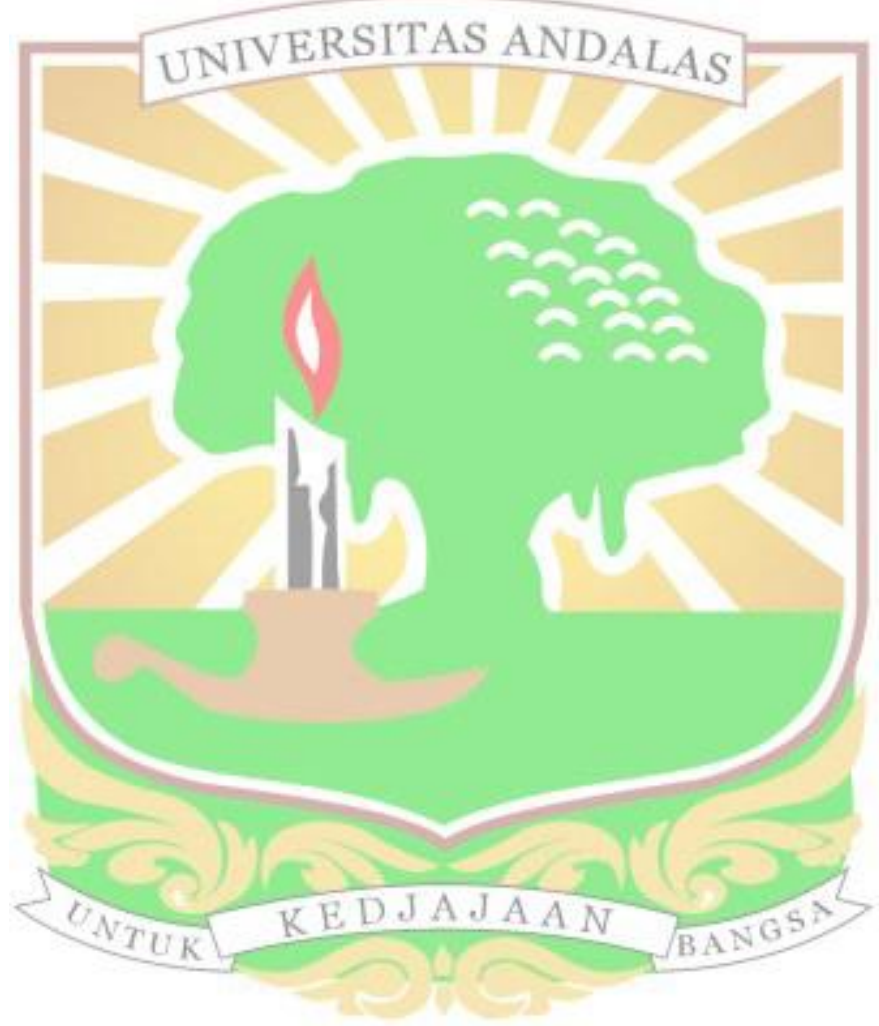

